\title{
Vigor of needleandthread and blue grama after short dura- tion grazing
}

P.E. REECE, R.P. BODE, AND S.S. WALLER

\section{Abstract}

Graxing treatments were applied to pastures in western Nebraska from 1980 through 1983 to examine the influence of short duration grazing (SDG) on plant vigor. The 3 treatments were: (1) 4 years of SDG, (2) 3 years of SDG followed by 1 year of rest, and (3) 4 years of rest. Total nonstructural carbohydrate (TNC) concentrations of stem bases, mean tiller weight, and tiller number/plant of etiolated growth, and paired differences in spring growth between covered and uncovered plants were used to evaluate vigor of needleandthread (Stipa comata Trin. \& Rupr.) and blue grama [Bouteloua gracilis (HBK) Lag. ex Grifinths]. Two 7-pasture, 1-herd SDG systems were used. Length of use and deferment periods, stocking density, stocking rate, and sequence of pasture use were constant throughout the study.

Graxing treatments reduced the vigor of both study species, but the vigor of blue grama was more sensitive to treatments than needleandthread. Levels of TNC in needleandthread were not affeeted by graxing treatments. Concentrations of TNC in blue grama recovered to levels of ungrazed plants after 1 year of reat in some but not all pastures. Graxing increased the number of tillers/ plant, but reduced total organic reserves of both species as measured by etiolated growth. Assimilates produced in early spring growth appeared to be more important for tiller initiation in plants that had been grazed than in ungrazed plants.

Key Words: carbohydrate reserves, etiolated growth, tiller number, Stipa comata, Bouteloua gracilis

The influence of short duration grazing (SDG) on energy reserves of native perennial grasses has not been reported. Knowledge of how grazing management affects energy reserves of native grass species will provide a better foundation for the development and combination of grazing strategies over seasons and years (White 1973). Research in Africa and the United States has examined species composition, basal cover, density, frequency, tiller demography, and aboveground net primary production, all of which are ecologically important variables (Denny and Steyn 1977, Heitschmidt et al. 1982, Brown and Stuth 1984). However, shortterm grazing studies may not detect the potential for significant changes in plant species because of the apparent "plasticity" of native vegetation (Gammon 1978).

Effects of a wide spectrum of clipping treatments on carbohydrate concentrations in native range plants have been studied over time periods of 1 to 4 years (Trlica and Cook 1971, Owensby et al. 1974, Buwai and Trlica 1977b). Relatively few carbohydrate studies have utilized grazing animals to apply defoliation treatments (Owensby et al. 1977). Differences between clipping and grazing on rangeland are primarily associated with seasonal changes in selective herbivory (Streeter et al. 1968, Trlica 1977).

Comparisons of treatments based upon carbohydrate concentrations are also dependent upon the relative contribution of carbohydrate sinks at the time of sampling and the quality of collection and preparation procedures (Perry and Moser 1974). Esti-

\footnotetext{
Authors are associate professor and former graduate student, Agronomy Department, University of Nebraska and Panhandle Research and Extension Center, Scottsbluff 69361; and professor, Agronomy Department, University of Nebraska, Lincoln 68583.

Appreciation is expressed to Gordon D. Moeller and Charles P. Moser for their dedicated assistance in the completion of this project.

Published as Paper 8120, Journal Series, Nebraska Agricultural Experiment Station.

Manuscript accepted 15 January 1988.
}

mation of total energy reserves in field studies requires extensive excavation of root systems or exhaustion of etiolated growth (Peterson 1962, McKendrick and Sharp 1970). Herbage growth response to defoliation may also be poorly correlated with total nonstructural carbohydrate (TNC) measurements (Brown 1985, Richards and Caldwell 1985).

The objectives of this study were to evaluate the effect of 4 years of SDG and 1 year of rest following 3 years of SDG on vigor of needleandthread (Stipa comata Trin. \& Rupr.) and blue grama [Bouteloua gracilis (HBK) Lag. ex Griffiths] as reflected by TNC concentrations in stem bases and etiolated growth response as a quantitative index of total organic reserves. Plant names are presented according to GPFA (1986).

\section{Study Area and Methods}

The study was conducted on the University of Nebraska Panhandle Experimental Range (PER), located $19 \mathrm{~km}$ northwest of Scottsbluff, Nebraska. Pastures are composed primarily of sands range sites with soils that are Valent fine sands (Mixed Mesic Ustic Torripsamment). Mean annual precipitation is $345 \mathrm{~mm}, 73 \%$ of which occurs from May to September (NOAA 1984). Annual precipitation was $212,292,386$, and $410 \mathrm{~mm}$ in 1980 through 1983 , respectively.

Two 7-pasture-1-herd short duration grazing systems were initiated at the PER in 1980 . These replicate systems were used for 124 days during the growing season from late May or early June through September from 1980 through 1983. Each system was composed of seven 7.5-ha pastures. One 0.04-ha exclosure was constructed in each pasture in 1980. All rangeland in these pastures had been managed under deferred rotation at $1.0 \mathrm{AUM} /$ ha for the preceding 4 years.

Adjacent pastures from each system were grazed at the same time during 4 days of grazing followed by 24 days of deferment. Use and deferment periods were constant and pastures were grazed in the same sequence throughout the study. The first and fifth sequence pasture were used for this project. Sequence 1 pastures were grazed 5 times for a total of 20 days and a seasonal stocking rate of $2.5 \mathrm{AUM} / \mathrm{ha}$. Sequence 5 pastures were grazed 4 times for a total of 16 days and a seasonal stocking rate of $2.0 \mathrm{AUM} / \mathrm{ha}$. The Soil Conservation Service recommended stocking rate for season long grazing at the study site was $1.0 \mathrm{AUM} / \mathrm{ha}$.

Comparison of sequence 1 and 5 provides a contrast of plant species response under 2 different types of SDG management conditions. Needleandthread and blue grama were the dominant cool- and warm-season species, respectively, in all 4 pastures used in this study. Use of sequence 1 pastures was distributed over a 28-day longer time period than sequence 5 pastures. Grazing began 16 days earlier and ended 12 days later in sequence 1 than sequence 5 . The stocking rate in sequence 1 was $25 \%$ greater than in sequence 5.

Three grazing treatments were applied from 1980 through 1983 in each pasture: (1) Grazed, 4 years of SDG; (2) Grazed/Rest, 3 years of SDG followed by 1 year of rest inside randomly located 1.3- $\mathrm{m}^{2}$ wire cages; and (3) Ungrazed, 4 years inside permanent exclosures. Yearling steers with an initial weight of 230 to 270 $\mathrm{kg} / \mathrm{hd}$ were grazed at a stocking rate of $0.5 \mathrm{AUM} / \mathrm{ha}$ per use period and a stocking density of $3.8 \mathrm{AU} / \mathrm{ha}$.

Six $10 \mathrm{~cm}$ deep samples of needleandthread and blue grama sod 
were dug in each pasture in March 1984 before grasses had broken dormancy. Samples were transported on dry ice to the laboratory, and stored at $-7^{\circ} \mathrm{C}$. The bottom $3 \mathrm{~cm}$ of stem bases were dried in a forced air oven for 42 hours at $70^{\circ} \mathrm{C}$, ground through a $0.5-\mathrm{mm}$ screen, and analyzed for total nonstructural carbohydrate (TNC) concentrations (Smith 1981). Despite differences in photosynthetic mechanisms the primary polymer stored by both species is starch (Smith 1968). Both species also have the greatest percentage of carbohydrate reserves in stem bases (White 1973, Perry and Moser 1974). Mylase 100 was used to hydrolyze the starch to monomers. Reducing power was measured by the Schaeffer-Somogyi copperiodometric titration method as described by Heinze and Murneek (1940), and modified by Smith (1981). TNC was calculated on a percentage dry organic matter basis using a glucose standard. Samples were ashed at $600^{\circ} \mathrm{C}$ to correct for soil contamination.

Twenty locations were randomly selected for covered plant growth in each pasture and each permanent exclosure in March 1984. Treatments used in the covered plant study did not include grazed/rest. Two plants of blue grama and needleandthread with similar basal area were selected per sample location in the pastures. One plant of each species was selected per sample location in permanent exclosures. Needleandthread plants were clipped to a height of $2 \mathrm{~cm}$ above the ground to avoid removal of overwintered tillers. Blue grama plants were clipped at ground level. Five grams of diazinon granules [0,0-diethyl 0-(2-isopropyl-6-methyl-4-pryimidinyl) phosphorothioate] of $2 \%$ active ingredient was sprinkled over the clipped plants to prevent insect infestations. Clipped plants were covered with number 10 cans $\left(186 \mathrm{~cm}^{2} \times 17 \mathrm{~cm}\right)$ that had been painted white. If any plant had a basal area greater than that of the can base, a trowel blade was pushed to a depth of $5 \mathrm{~cm}$ around the edge of the can to sever any roots or stems that might translocate materials to covered tillers. Wire cages were placed around the cans to prevent disturbance.

Etiolated growth was clipped at the ground level on 17 May and 13 June for needleandthread and blue grama, respectively. Proximal uncovered plants of the same species and of comparable basal area were harvested concurrently with each covered plant. Tillers were bagged separately for each plant, placed on dry ice, and returned to the laboratory. Harvested tillers were counted and then dried in a microwave oven under high power for 15 minutes and weighed. Average tiller weight was calculated by dividing total dry plant weight by number of tillers.

A randomized complete block experimental design with pastures as blocks and plants as experimental units was used for this study. Mean tiller number and tiller weight per plant and TNC concentrations were evaluated by analyses of variance using the general linear models procedure of Statistical Analytical Systems (Ray 1982). Duncan's multiple range test was used for mean separation. Differences in tiller characteristics between covered plants and their proximal uncovered counterparts were calculated and analyzed with the same statistical procedures. Treatment variances were not different among pastures and there were no treatment $X$ pasture interactions. Data were therefore pooled by species across pastures to test for treatment effects.

\section{Results and Discussion}

\section{Carbohydrates}

Grazing treatments and sequence had no effect on early spring TNC concentrations in stem bases of needleandthread (Table 1). Concentrations of TNC in needleandthread averaged $14.9 \%$ over all treatments. Mean concentrations of TNC observed in this study were higher than means reported for needleandthread by Trlica and Cook (1971).

Concentrations of TNC in ungrazed blue grama were similar to results reported by Trlica et al. (1977) and Menke and Trlica (1981) for unclipped plants collected in the fall. Four years of grazing reduced TNC concentrations in blue grama stem bases in both sequences compared to ungrazed plants (Table 1). Plants with 1
Table 1. Total nonstructural carbohydrate concentrations in needleandthread and blue grama stem bases sampled in early spring under three graxing treatments for two sequences of pasture use.

\begin{tabular}{lcccc}
\hline \hline & & \multicolumn{3}{c}{ Total nonstructural carbohydrates } \\
\cline { 3 - 5 } Species & Sequence & \multicolumn{3}{c}{ Grazing treatment } \\
\cline { 3 - 5 } Needleandthread & 1 & Grazed & Grazed/Rest & Ungrazed \\
\cline { 3 - 5 } & 5 & $14.9 \mathrm{a}$ & $14.4 \mathrm{a}$ & $13.5 \mathrm{a}$ \\
& $\mathrm{P}>\mathrm{F}^{2}$ & $\frac{16.3 \mathrm{a}}{\mathrm{NS}}$ & $\frac{15.9 \mathrm{a}}{\mathrm{NS}}$ & $\frac{14.3 \mathrm{a}}{\mathrm{NS}}$ \\
Blue grama & 1 & $3.5 \mathrm{~b}$ & $5.7 \mathrm{a}$ & $6.6 \mathrm{a}$ \\
& 5 & $\frac{3.9 \mathrm{~b}}{4}$ & $\frac{4.1 \mathrm{~b}}{6 *}$ & $\frac{6 \mathrm{a}}{\mathrm{NS}}$ \\
& $\mathrm{P}>\mathrm{F}^{2}$ & $\mathrm{NS}$ & & $*$
\end{tabular}

IMeans within rows followed by the same letter are not significantly different $(P>0.05)$

2Probability of differences between sequences, $* * P \leq 0.01, \mathrm{NS}=$ Not Significant $(P>0.05)$

year of rest had TNC concentrations as high as ungrazed plants in sequence 1 but not in sequence 5 .

The recovery of the rested plants in sequence 1 was similar to responses observed by Trlica et al. (1977) after blue grama had been defoliated 6 times over 2 growing seasons. Plants had been exposed to grazing 15 times over 3 growing seasons in sequence 1 . In contrast, a year of rest appeared to be insufficient time for blue grama plants in sequence 5 to restore TNC concentrations to ungrazed levels even though plants had been exposed to grazing only 12 times over 3 years. Albertson et al. (1953) observed that more than 3 years of rest were required for blue grama to recover vigor following intensive defoliation for 6 years.

\section{Tiller Number}

Covered plants of needleandthread and blue grama produced an average of 53 and 51 tillers/plant, respectively (Table 2). Grazing treatments caused significant differences that were inconsistent between sequences. Grazed needleandthread plants had $67 \%$ more tillers in sequence 1 but, $37 \%$ fewer tillers than ungrazed plants in sequence 5. Grazing had no effect on blue grama tillers/covered plant in sequence 1 but, increased tiller number over the ungrazed treatment by $29 \%$ in sequence 5 .

There were more tillers/covered-plant in sequence 1 than 5 for both species under the grazed treatment and for blue grama in the ungrazed treatment (Table 2). Needleandthread plants in the ungrazed treatment had more tillers/covered-plant in sequence 5 than 1.

The sum of the mean tiller number/covered-plant plus the mean paired difference (uncovered minus covered) in tiller numbers equals the mean number of tillers produced for uncovered plants (Table 2). Grazing increased tiller number in uncovered plants of both species in each sequence compared to the ungrazed treatment.

Uncovered plants developed more tillers/plant than their covered counterparts (Table 2). Productivity of grasses depends on the ability of a plant to initiate tillers and subsequent tiller growth (Laude 1972). Exclusion of light reduces tiller initiation (Mitchell and Coles 1955), but the degree of reduction was much greater in plants exposed to grazing than in ungrazed plants for both species. This pattern occurred irrespective of treatment differences in tiller number/covered-plants.

Paired differences between covered and uncovered counterparts indicated that organic reserves were probably a major factor in tiller initiation which agrees with the findings of Friend (1965). The relative increase in tiller number of uncovered plants indicates that assimilates produced in early spring growth may have been more important for tiller development in plants exposed to grazing than in ungrazed plants. The number of needleandthread and blue grama tillers/plant increased by 60 and $83 \%$, respectively, when 
Table 2. Mean tiller number per plant for needleandthread and blue grama under grazed and ungrazed treatments for two sequences of pasture use.

\begin{tabular}{|c|c|c|c|c|c|c|c|}
\hline \multirow[b]{2}{*}{ Species } & \multirow[b]{2}{*}{ Sequence } & \multicolumn{3}{|c|}{ Covered plants } & \multicolumn{3}{|c|}{$\begin{array}{c}\text { Paired differences } \\
\text { (Uncovered minus covered plants) }\end{array}$} \\
\hline & & Grazed & Ungrazed & $\mathbf{P}<\mathbf{F}^{2}$ & Grazed & Ungrazed & $\mathbf{P}>\mathrm{F}^{2}$ \\
\hline \multirow[t]{2}{*}{ Needleandthread } & $\begin{array}{l}1 \\
5\end{array}$ & $\begin{array}{l}65 \mathrm{a} \\
46 \mathrm{~b} \\
\end{array}$ & $\begin{array}{l}39 b \\
62 a\end{array}$ & $* *$ & $\begin{array}{l}42 \mathrm{a} \\
25 \mathrm{~b} \\
\end{array}$ & $\begin{array}{c}19 \mathrm{a} \\
4 \mathrm{b \#} \\
\end{array}$ & $\begin{array}{l}\text { ** } \\
* *\end{array}$ \\
\hline & Mean & 56 & 50 & NS & 33 & 12 & ** \\
\hline \multirow[t]{2}{*}{ Blue grama } & $\begin{array}{l}1 \\
5\end{array}$ & $\begin{array}{r}57 a \\
49 b \\
\end{array}$ & $\begin{array}{l}57 a \\
38 b \\
\end{array}$ & NS & $\begin{array}{r}37 a \\
50 a \\
\end{array}$ & $\begin{array}{r}11 \mathrm{a} \\
20 \mathrm{a} \\
\end{array}$ & $* *$ \\
\hline & Mean & 53 & 48 & NS & 44 & 16 & $* *$ \\
\hline
\end{tabular}

Means withing grazing treatments and within species followed by the same letter are not significantly different $(P>0.05)$.

${ }_{2}^{2}$ Probability of differenes between grazing treatments $* P \leq 0.05, \cdots P \leq 0.01, \mathrm{NS}=$ Not Significant $(P>0.05)$.

\#Not significantly different than 0 .

grazed plants were not covered. Ungrazed plants of needleandthread and blue grama produced only 28 and $36 \%$ more tillers/ plant, respectively, when not covered.

\section{Tiller Weight}

Overall mean tiller weight of covered needleandthread and blue grama plants was 4.9 and $6.2 \mathrm{mg} /$ tiller, respectively (Table 3 ). Four years of SDG appreciably reduced mean tiller weight of covered plants of both species in both sequences compared to the ungrazed treatment (Table 3). Ungrazed needleandthread tillers were 25 and $64 \%$ heavier than grazed tillers in sequence 1 and 5, respectively. Blue grama tillers were 41 and $43 \%$ heavier in the ungrazed vs. grazed treatment in sequence 1 and 5 , respectively. While sequence did not affect mean needleandthread tiller weight/covered-plant in the ungrazed treatment, tillers were $45 \%$ heavier in sequence 1 than sequence 5 under SDG. Covered blue grama tillers were about $40 \%$ heavier in sequence 1 than sequence 5 under both grazing treatments.

Mean tiller weight of uncovered plants was greater than covered plants in all cases (Table 3). Paired differences in mean tiller weight between covered and uncovered plants were greater for ungrazed treatments for both species in sequence 5 and for blue grama in sequence 1. Grazing treatments did not affect paired differences for needleandthread in sequence 1 . Sequence had no effect on paired differences for needleandthread within grazing treatments. Paired differences for blue grama were 47 and $37 \%$ greater in sequence 1 than sequence 5 under grazed and ungrazed treatments, respectively. All significant declines in paired differences between sequences and grazing treatments coincided with significant declines in mean tiller weight/covered-plant. Declines in mean tiller weight caused by grazing were not compensated for by spring growth except for needleandthread in sequence 1 .

\section{Sequences}

A comparison between the 2 types of grazing management represented by sequence 1 and 5 demonstrates the influence of range resources on the design and management of optimum grazing systems. The upper limit of stocking rate may not become apparent for several years when drought is encountered. Drought occurred in the first year of this study, but visual differences in perennial grasses between sequences and grazing treatments did not occur until the fourth year. Vegetation changes coincided with differences observed in this study and became pronounced under severe drought conditions in 1985.

If an additional use period and a $25 \%$ increase in stocking rate had not been applied to sequence 1 the data may have been interpreted as a response to early vs. late pasture use sequences. However, plant vigor was generally better in sequence 1 than sequence 5 pastures for both species even though grazing in sequence 1 began before and ended after use of sequence 5 pastures.

Number of use periods per pasture was not an accurate measure of the frequency of defoliation for the study species. Grazing began 16 days earlier in sequence 1 than 5 , which was generally before steers began to utilize blue grama. Streeter et al. (1968) observed that steer diets reflected an increased preference for blue grama starting in early June at stocking densities comparable to those used in this study. Grazing ended 12 days later in sequence 1 than 5 at a time when steers generally utilized needleandthread fall growth more than blue grama. Consequently, steers tended to use blue grama in 3 of 5 vs. 4 of 4 use periods in sequence 1 and 5 , respectively.

Frequency and basal area of needleandthread were comparable among the 4 study pastures at the beginning of the grazing treatments. While the relative frequency of occurrence of blue grama ranged from $50-74 \%$ among pastures, basal area was approximately 3 times greater in sequence 5 than 1 . Diversity of other perennial grasses was also lower in sequence 5 than sequence 1 pastures. Significantly lower mean tiller weight for blue grama in sequence 5 vs. 1 following 4 years of rest indicates that differences in forage production potential may have occurred between sequence locations (Table 3). These initially subtle differences may have

Table 3. Mean tiller weight per plant for needleandthread and blue grama under grazed and ungrazed treatments for two sequences of pasture use.

\begin{tabular}{|c|c|c|c|c|c|c|c|}
\hline \multirow[b]{2}{*}{ Species } & \multirow[b]{2}{*}{ Sequence } & \multicolumn{3}{|c|}{ Covered plants ${ }^{1}$} & \multicolumn{3}{|c|}{$\begin{array}{c}\text { Paired differences } 1 \\
\text { (Uncovered minus covered plants) }\end{array}$} \\
\hline & & Grazed & Ungrazed & $\mathbf{P}<\mathbf{F}^{2}$ & Grazed & Ungrazed & $\mathbf{P}>\mathrm{F}^{2}$ \\
\hline \multirow[t]{2}{*}{ Needleandthread } & $\begin{array}{l}1 \\
5\end{array}$ & $\begin{array}{l}4.8 \mathrm{a} \\
3.3 \mathrm{~b} \\
\end{array}$ & $\begin{array}{r}6.0 \mathrm{a} \\
5.4 \mathrm{a} \\
\end{array}$ & $*$ & $\begin{array}{l}12.3 \mathrm{a} \\
11.3 \mathrm{a} \\
\end{array}$ & $\begin{array}{l}10.7 \mathrm{a} \\
13.2 \mathrm{a} \\
\end{array}$ & $\begin{array}{l}\text { NS } \\
* *\end{array}$ \\
\hline & Mean & 4.1 & 5.7 & $* *$ & 11.1 & 12.0 & NS \\
\hline \multirow[t]{2}{*}{ Blue grama } & $\begin{array}{l}1 \\
5\end{array}$ & $\begin{array}{l}5.9 \mathrm{a} \\
4.2 \mathrm{~b}\end{array}$ & $\begin{array}{l}8.3 \mathrm{a} \\
6.0 \mathrm{~b}\end{array}$ & $\begin{array}{l}* * \\
* *\end{array}$ & $\begin{array}{l}10.6 \mathrm{a} \\
7.2 \mathrm{~b}\end{array}$ & $\begin{array}{l}14.0 \mathrm{a} \\
10.2 \mathrm{~b}\end{array}$ & $\begin{array}{l}* * \\
* *\end{array}$ \\
\hline & Mean & 5.1 & 7.2 & ** & 8.9 & 12.1 & ** \\
\hline
\end{tabular}

'Means within grazing treatments and within species followed by the same letter are not significantly different ( $P>0.05$ ).

2Probability of differences between grazing treatments, ${ }^{*} P \leq 0.05, * * P \leq 0.01$, NS $=$ Not Significant $(P>0.05)$ 
influenced the degree and frequency of defoliation of the study species.

\section{Study Species}

The vigor of blue grama was more sensitive to grazing treatments than needleandthread even though this short grass species is considered to be very tolerant to grazing (Buwai and Trlica 1977a, Menke and Trlica 1983). The tolerance of needleandthread to grazing has been reported as relatively sensitive to relatively resistant (Peterson 1962). Differences in vigor response between the 2 study species may have been caused by differences in phenological stage at which grazing was initiated (Brown and Stuth 1984). Needleandthread was in the late boot to inflorescence stage of development before grazing was initiated in any pasture. While needleandthread may have been less tolerant of grazing after setting seed (Wright 1967), its relative palatability was low compared to blue grama (Streeter et al. 1968). Blue grama was exposed to grazing at all stages of phenological development. Range plants may also respond differently to grazing management under different precipitation regimes (Menke and Trlica 1983). Olson et al. (1985) observed that blue grama was favored by extreme variation in year to year precipitation while needleandthread response was directly related to cumulative precipitation. Needleandthread may have been favored over blue grama in our study because total annual precipitation increased continually from $212 \mathrm{~mm}$ in 1980 to $410 \mathrm{~mm}$ in 1983.

\section{Summary}

This study reports the effects of 3 and 4 years of a specific type of short duration grazing on the vigor of needleandthread and blue grama. Short duration grazing at high stocking rates and fixed time periods of grazing and deferment was used to apply grazing treatments to the same pastures each year. Because SDG was not compared to other grazing systems, the results do not represent a test of grazing management strategies. Changes in plant vigor were caused by grazing treatments that were applied with SDG.

Grazing treatments reduced the vigor of both study species, but the vigor of blue grama was more sensitive to treatments than needleandthread. Differences in phenology between the study species and in the diversity of other perennial grasses among pastures appeared to cause greater selection for blue grama by yearling steers. A continual increase in total annual precipitation during the 4 years over which treatments were applied may have also favored needleandthread.

Treatments caused more changes in etiolated plant growth than in TNC concentrations of stem bases. Grazing increased tiller number/plant but generally reduced mean tiller weight. Use of paired plants of comparable basal area for the study of etiolated growth provided valuable information. Tiller number and mean tiller weight/plant were consistently greater for uncovered than covered plants. All declines in paired differences (uncovered minus covered) between sequences of pasture use and grazing treatments coincided with significant declines in mean tiller weight of etiolated plant growth. Assimilates produced in early spring growth may have a greater influence on the percentage of buds that are stimulated in grasses that have been grazed compared to ungrazed grasses.

Herbage growth response of needleandthread did not coincide with measurements of TNC concentrations in crowns. Similar observations were made by Brown (1985) and Richards and Caldwell (1985). They stated that regrowth was inconsistent with theories of growth dependence on assimilated reserves stored in roots or crowns. Assimilate allocation strategies were also species specific. Richards and Caldwell (1985) concluded that 89 to $99 \%$ of regrowth tissue was derived from current photosynthesis in Agropyron desertorum (Fisch. ex Link) Schult. and $A$. spicatum (Pursh) Scribn. \& Smith. Etiolated plant growth does coincide with regrowth and appears to be a more reliable index for plant response to defoliation than TNC.
It appears that the probability of sustaining SDG at high stocking rates will depend upon adjustments in the number of grazing periods to account for variations in species diversity. Circumstantial evidence in this study indicates that the number of grazing periods on rangeland should be reduced as the diversity of species and length of grazing season decline. A test of this hypothesis should be conducted over a time span that goes beyond the period of plasticity in native vegetation (Gammon 1978).

\section{Literature Cited}

Albertson, F.W., A. Riegel, and J.L. Launchbaugh, Jr. 1953. Effects of different intensities of clipping on shortgrasses in west-central Kansas. Ecol. 34:1-20.

Brown, J.R., and J.W. Stuth. 1984. The probability of individual tillers being grazed in short duration grazing. pp 197-203. In: Forage and Grassl. Conf., Amer. Forage. and Grassl. Counc., Texas Forage and Grassl. Counc. and Texas A\&M Univ., College Station, Texas.

Brown, R.F. 1985. The effect of severe defoliation on the subsequent growth and development of five rangeland pasture grasses of southwestern Queensland. Australian J. Ecol. 10:335-343.

Buwai, M., and M.J. Trlica. 1977a. Defoliation effects on root weights and total nonstructural carbohydrates of blue grama and western wheatgrass. Crop Sci. 17:15-17.

Buwai, M., and M.J. Trlica. 1977b. Multiple defoliation effects on herbage yield, vigor and total nonstructural carbohydrates of five range species. J. Range Manage. 30:164-171.

Denny, R.P., and J.S.H. Steyn. 1977. Trials of multi-paddock grazing systems on Veld. 2. A comparison of a 16-paddocks-to-one-herd system with a four-paddock-to-one-herd system using breeding cows. Rhod. J. Agr. Res. 15:119-128.

Friend, D.J.C. 1965. Tillering and leaf production in wheat as affected by temperature and light intensity. Can. J. Bot. 43:1063-1076.

Gammon, D.M. 1978. A review of experiments comparing systems of grazing management on natural pastures. Proc. Grassld. Soc. So. Afr. 13:75-82.

Great Plains Flora Association. 1986. Flora of the Great Plains. T.M. Barkley (ed). University of Kansas. Lawrence, Kans.

Heinze, P.H., and A.E. Murneek, 1940. Comparative accuracy and efficiency in determinations of carbohydrates in plant material. Missouri Agr. Exp. Sta. Res. Bull. 314.

Heitschmidt, R.K., D.L. Price, R.A. Gordon, and J.R. Frasure. 1982. Short duration grazing at the Texas Experimental Range: Effects on aboveground net primary production and seasonal growth dynamics. $J$. Range Manage. 35:367-372.

Laude, H.M. 1972. External factors affecting tiller development. pp. 147154. In: V.B. Youngerner and C.M. McKell (eds.). The biology and utilization of grasses. Academic Press, Inc., New York.

McKendrick, J.D., and L.A. Sharp. 1970. Relationship of organic reserves to herbage production in crested wheatgrass. J. Range Manage. 23:434-438.

Menke, J.W., and M.J. Trlica. 1981. Carbohydrate reserve, phenology and growth cycles of nine Colorado range species. J. Range Manage. 34:269-277.

Menke, J.W., and M.J. Trlica. 1983. Effects of single and sequential defoliations on the carbohydrate reserves of four range species. J. Range Manage. 36:70-74.

Mitchell, K.J., and S.T.J. Coles. 1955. Effect of defoliation and shading on short-rotation ryegrass. N.Z.J. Sci. Technol. Sect. A 36:586-604.

National Oceanic and Atmospheric Administration. 1984. Climatological data for Nebraska. U.S. Dep. of Commerce, volume 89.

Olson, K.C., R.S. White, and B.W.Sindelar. 1985. Response of vegetation in the northern Great Plains to precipitation amount and grazing intensity. J. Range Manage. 38:357-361.

Owensby, C.E., J.R. Rains, and J.D. McKendrick. 1974. Effects of one year of intensive clipping on big bluestem. J. Range Manage. 27:341-343.

Owensby, C.E., E.F. Smith, and J.R. Rains. 1977. Carbohydrate and nitrogen reserve cycles for continuous, season-long, and intensive-early stocked Flint Hills bluestem range. J. Range Manage. 30:258-260.

Perry, L.H., Jr., and L.E. Moser. 1974. Carbohydrate and organic nitrogen concentrations within range grass parts at maturity. J. Range Manage. 27:276-278.

Peterson, R.A. 1962. Factors affecting resistance to heavy grazing in needleandthread grass. J. Range Manage. 15:183-189. 
Ray, A.A. (ed.) 1982. SAS User's Guide Statistics. 1982 edition. SAS Institute Inc., North Carolina.

Richards, J.H., and M.M. Caldwell. 1985. Soluable carbohydrates, concurrent photosynthesis and efficiency in regrowth following defoliation: A field study with Agropyron species. J. Appl. Ecol. 22:907-920.

Smith, D. 1968. Classification of several native North American grasses as starch of fructosan accumulators in relation to taxonomy. J. Brit. Grassl. Soc. 23:306-309.

Smith, D. 1981. Removing and analyzing total nonstructural carbohydrates from plant tissue. Wisconsin Agr. Exp. Sta. Res. Rep. R-2107.

Streeter, C.L., D.C. Clanton, and O.E. Hoehne. 1968. Influence of advance in season on nutritive value of forage consumed by cattle grazing western Nebraska native range. Nebraska Agr. Exp. Sta. Bull. 277.
Trlica, M.J., Jr. 1977. Effects of frequency and intensity of defoliation on primary producers on arid and semi-arid rangelands. p. 27-55. In: The impact of herbivores on arid and semi-arid rangelands. Aust. Range. Soc. Perth. Western Aust.

Trlica, M.J., M. Buwai, and J.W. Menke. 1977. Effects of rest following defoliations on the recovery of several range species. J. Range Manage. 30:21-27.

Trlica, M.J., Jr., and C.W. Cook. 1971. Defoliation effects on carbohydrate reserves of desert species. J. Range Manage. 24:418-425.

White, L.M. 1973. Carbohydrate reserves of grasses: A review. J. Range Manage. 26:13-18.

Wright, H.A. 1967. Contrasting responses of squirreltail and needleandthread to herbage removal. J. Range Manage. 20:398-400. 